\title{
Eluvial losses of Ca from Umbric Albeluvisols Abruptic produced by different doses of lime: column experiment
}

\author{
OlgaPavlova $^{1}$, Andrey Litvinovich ${ }^{1}$, Anton Lavrishchev $^{2}$, Vladimir Bure $^{1,3}$, Elmira Saljnikov ${ }^{4 *}$ \\ ${ }^{1}$ Agrophysical Research Institute, Grazhdanskiy 14, 195220 St. Petersburg, Russia \\ ${ }^{2}$ St. Petersburg State Agrarian University, Peterburgsoye 2, 196601 St. Petersburg, Pushkin, Russia \\ ${ }^{3}$ St. Petersburg State University, Universitetskaya Emb. 7/9, 199034 St. Petersburg, Russia, \\ ${ }^{4}$ Soil Science Institute, Teodora Drajzera 7, 11000 Belgrade, Serbia \\ *Corresponding author:Saljnikov Elmira, Teodora Drajzera 7, 11000, Belgrade, \\ Serbiasoils.saljnikov@gmail.com
}

\begin{abstract}
Losses of soil calcium due to migration from Umbric Albeluvisols Abruptic soil meliorated by various doses of chalk were studied in column experiment with 16 washings. It has been established that the dynamic of calcium leaching from soil limed with optimal dose (1) and increased dose (2) is of a similar nature. In both treatments in the first 5 and 3 washes, respectively, there was a sharp decrease in the amount of calcium in the soil as described by exponential model. Starting from 6 and 4 washes, respectively, stabilization in Ca losses occurred. It was found that an increase in the chalk dose by 2.7 times increases the leaching of calcium by 4.8 times. It was concluded that an attempt to create in soil a certain reserve of available calcium for plants by increasing the dose of a finely ground ameliorant is ineffective because it increases unproductive losses of calcium. It has been suggested that in the soil there is a buffer system: exchangeable calcium $\leftrightarrow$ calcium of soil solution, which even in the conditions of intensive wetting maintains the presence of a certain amount of water-soluble calcium.
\end{abstract}

Keywords: calcium losses; liming; empirical models

\section{INTRODUCTION}

Liming of acid soils is a world-wide practice in agriculture (Adomaitis et al., 2013; Paradelo et al., 2015; Litvinovich et al., 2017; Holland et al., 2018) aimed to reduce soil acidity and to replenish leached out soil cations. 
From all the cations migrating in soil, calcium is the most mobile one(Litvinovich et al., 2012;Adomaitis et al., 2013;Fernández-Sanjurjo, 2014;Goulding, 2016). In humid climate the main cause of calcium losses is a vertical migration with atmospheric precipitations (Kopáček et al., 2017).

High mobility of $\mathrm{Ca}$ in soils of percolation and periodically percolation types of water regime is associated with a large ionic radius of $\mathrm{Ca}(1,06 \AA$ ) (Sekine et al., 2017) that does not allow it to participate in the construction of the crystal lattice of minerals and be fixed in soils.

According to Shilnikov et al., (1987) exchangeable Ca is resistant to migration with washing water, but it is in equilibrium with the calcium of the soil solution (FernándezSanjurjo, 2014).

Bakina (2012) explains the high mobility of $\mathrm{Ca}$ in soils of podzolic type by their weak ability to retain $\mathrm{Ca}$ preconditioning its rapid removal from soil profile.

Thus, the leaching out of $\mathrm{Ca}$ from soils of the podzolic type is associated with the climatic conditions of the region, as well as with the physico-chemical properties of the soils.

The methods used to study the loss of $\mathrm{Ca}$ from soils due to leaching can be divided into: lysimetric (Shepherd and Bennett, 1998; Bélangeret al., 2008), chromatographic (Youngil et al. 2009; Kaurichev and Yashin, 1973), tracer method(Lehmann and Schroth, 2003), column experiments (Litvinovich et al., 1999; Pousada-Ferradás, et al., 2012), calculation of Ca losses with drainage runoff (Pestryakov, 1987), calculation method for studying Ca losses from soils in long field experiments (Shilnikov et al., 2004).

To date, an extensive experimental material has been accumulated in the early literature on the amount of leachable calcium from the soils because of washing (Lapenis, 2008; Youngil et al., 2009; Adomaitis et al., 2013). It was found that the washout intensity depends on the initial calcium content in the soils, the amount of precipitation, the granulometric composition of soils, the dose of the applied ameliorant, the amount of fertilizer used, etc. (Litvinovich et al., 2012). However, there is few new researches studying calcium transport from lime with leachate (Kabrick et al., 2011) and secondly, collection of only experimental material is often not sufficient to explain all the mechanisms of $\mathrm{Ca}$ transport with leaching water, because such data differ quantitatively and therefore are not comparable. 
Because in soil, the vertical movement of waters affects the amount of solute calcium leached from soil and applied lime (Kabrick et al., 2011), the systematic tests of eluvial losses of $\mathrm{Ca}$ with leachate from repeated washing is useful and important for sustainable use of lime fertilizers on acidic soil. Such information is best obtained from the studies with large number of tests providing the data and regularities, which allow building corresponding empirical models and further to predict the $\mathrm{Ca}$ losses and to maintain correct liming of soils.

Aim of this study was to establish the intensity of calcium migration from the meliorated soddy-podzolic sandy loam soil due to repeated washings in a column model experiment with empirically description of the processes of $\mathrm{Ca}$ migration from soil limed with various doses in time.

\section{MATERIALS AND METHODS}

The research on pot experiment was conducted on soddy-podzolic sandy loam soil (Umbric Albeluvisols Abruptic) (IUSS-WRB, 2007) selected under a natural perennial meadow in 2006-2010. In 2011 the column experiment was performed. The physicochemical characteristics of the soil were: $\mathrm{pH}_{\mathrm{KCl}} 4.1$; hydrolytic acidity (Ha)-5.4 mmol-eq. $100 \mathrm{~g}^{-1}$; humus content $-3.02 \%$; particle content less than $0.01 \mathrm{~mm}$ is $18.6 \%$.

Conversion chalk - a by-product of the nitric acid treatment of phosphate raw materials in the production of mineral fertilizers was used as an ameliorant after sieving through 0.25 mm mesh. The $\mathrm{CaCO}_{3}$ content in the chalk is $90 \%$.

The soil was limed with the doses of chalk corresponding to 0.9 (optimal) and 2.5 $\mathrm{Ha}$ (increased) from the total dose calculated by hydrolytic acidity. The dose corresponding to 2.5 $\mathrm{Ha}$ is not used in practice, but such accumulation of ameliorant can take place in individual soil foci with uneven application of the ameliorant over the field surface (Litvinovich, 2007). The mineral fertilizer was applied annually (0.2 g NPK per $1 \mathrm{~kg}$ of soil). The experiment lasted 5 years in three replications for each treatment. Each pot contained 5 $\mathrm{kg}$ of soil with packing density $-1.1 \mathrm{~g} \mathrm{~cm}^{-3}$. Growing crops were rapeseed, spring vetch, spring barley, spring rapeseed and spring rapeseed, successively.

After the completion of the experiment, the soil was removed from the vessels and placed in columns for washing. The mass of soil in each column was $600 \mathrm{~g}$. The replication of the column experiment was 4-fold. 
The washings were carried out with a precisely calculated amount of distilled water, simulating the volume of moisture percolating through the soil thickness every year, based on the data of mean annual precipitation in the Northwest of Russia that is around $600 \mathrm{~mm}$ (http://www.meteo.nw.ru/articles/index.php?id=2), and transpiration by plants and evaporation from the soil surface that is around $400 \mathrm{~mm}$ (Pestryakov, 1987).

Thus, $200 \mathrm{~mm}$ of precipitation percolates annually through the soil stratum. The amount of water required for a single wash of one column was calculated from the formula: $V=\frac{\pi * r^{2} * 200}{1000}$, where, $\pi=3.14 ; \mathrm{r}$-column radius, $\mathrm{mm}$;

According to the equation, $800 \mathrm{ml}$ of distilled water corresponds to the volume of moisture percolating yearly. In our studies, $400 \mathrm{ml}$ of water was used for a single washing. In total, 16 washings of each sample were carried out. The duration of the experiment was 1.5 months. The periods between the individual washings were 1-2 days. In each of the filtrate portions the concentration of calcium was determined by the complexometric method.

\section{RESULTS AND DISCUSSIONS}

The initial content of water-soluble calcium (WSCa) in virgin soil was $12.6 \mathrm{mg} \mathrm{kg}^{-1}$ soil. After completion of the experiment and before the washings, the content of WSCa in the treatment with a chalk dose corresponding to $0.9 \mathrm{Ha}$ was $160 \mathrm{mg} \mathrm{kg}^{-1}$ soil and in the treatment with $2.5 \mathrm{Ha}-660 \mathrm{mgkg}^{-1}$ soil.

Thus, during the dissolution of the ameliorant, the calcium compounds available for plants were formed and its reserves considerably exceeded the annual requirement of plants. This predetermined the high probability of loss of this element from the soil via leaching.

The amount of leachable calcium in the experiment depended on its initial content in the soil and the volume of leaked moisture (Table 1). The maximum content of leached calcium was in the first washing. As the experiment continued, the concentration of calcium in the washing waters decreased. 
Table 1 Leaching of $\mathrm{Ca}$ from soil limed with various doses of chalk in 16 washings, mg

\begin{tabular}{ccc}
\hline $\begin{array}{c}\text { Number of } \\
\text { washing }\end{array}$ & Liming at 0.9 hydrolytic acidity $(\mathrm{Ha})$ & Treatments \\
\hline 1 & $64.0 \pm 3,4$ & Liming at 2.5 hydrolytic acidity(Ha) \\
2 & $16.0 \pm 2,5$ & $462.0 \pm 15,3$ \\
3 & $8.0 \pm 1,1$ & $30.0 \pm 6,3$ \\
4 & $4.0 \pm 0,42$ & $18.0 \pm 3,4$ \\
5 & $3.2 \pm 0,19$ & $14.0 \pm 2,5$ \\
6 & $4.8 \pm 0,25$ & $8.8 \pm 1,1$ \\
7 & $4.0 \pm 0,20$ & $10.0 \pm 1,0$ \\
8 & $4.8 \pm 0,20$ & $8.4 \pm 0,3$ \\
9 & $2.4 \pm 0,12$ & $6.8 \pm 1,1$ \\
10 & $2.2 \pm 0,11$ & $7.9 \pm 1,3$ \\
11 & $6.1 \pm 0,73$ & $12.8 \pm 1,9$ \\
12 & $3.9 \pm 0,25$ & $10.9 \pm 0,9$ \\
13 & $2.7 \pm 0,14$ & $12.2 \pm 1,2$ \\
14 & $2.3 \pm 0,15$ & $9.3 \pm 1,5$ \\
15 & $1.8 \pm 0,11$ & $7.7 \pm 0,8$ \\
16 & $3.2 \pm 0,25$ & $7.7 \pm 0,7$ \\
\hline Total & 133.4 & $10.9 \pm 0,8$ \\
\hline
\end{tabular}

In the 16 washes of the soil limed with a dose of chalk corresponding to $0.9 \mathrm{Ha}, 133.4 \mathrm{mg}$ of $\mathrm{Ca}$ was removed, and from soil limed with a deliberately increased dose - $637.4 \mathrm{mg}$. So, an increase in the dose of chalk by 2.7 times increased the leaching of calcium by 4.8 times.

When washing the soil limed with $0.9 \mathrm{Ha}$ chalk the amount of WSCa in it decreased in 16 washes from $160 \mathrm{mg} \mathrm{kg}^{-1}$ to $21 \mathrm{mg} \mathrm{kg}^{-1}$ soils (84\% of the original content). In the treatment limed with a $2.5 \mathrm{Ha}$ chalk, the concentration of calcium decreased from $660 \mathrm{mg} \mathrm{kg}^{-1}$ to 22 $\mathrm{mgkg}^{-1}$ (i.e., for $97 \%$ ).

Thus, the results of the study show that the fund of calcium compounds prone to migrate in the soil after liming proved to be very significant. Regardless of the dose of chalk, most of the WSCa is easily removed from the soil by eluviation.

Figure 1 shows the dynamics of $\mathrm{Ca}$ (liming by $0.9 \mathrm{Ha}$ ) in all 16 washes. To describe the experimental data, an empirical dependence of the following type was obtained:

$$
y(x)=3,6877 \mathrm{e}^{\frac{5,915-0,5853 x}{x^{1,6}+0,985}+0,29 \cos (1,245(x-6,8))},
$$

where the argument $\mathrm{x}$ is a conditional time (integer value of argument - the number of washing).

As calculations have shown, the mean square deviation for the dependence (1) is $S=$ 0.89 , which indicates a good level of approximation to the experimental data. 
From the dependence and the analysis of the experimental data it follows that the dynamics of the index for liming with $0.9 \mathrm{Ha}$ can be divided into two phases: in the first five washes (1-5), a sharp exponential decrease occurred, from the sixth washing (6 - 16) a stabilization described by some fluctuations of the indicator at the same level occurred.

To describe the first phase (an exponential decrease), a simpler model was build:

$$
y(x)=e^{\frac{8,3175}{x^{1,03}+1}}
$$

The mean square deviation for the dependence (2) is $S=0.61$, which also indicates a good level of approximation of the experimental data. The quality of the approximation for the first five "washes" was higher, which is due to the simpler nature of the dynamics of the studied index in the first phase.

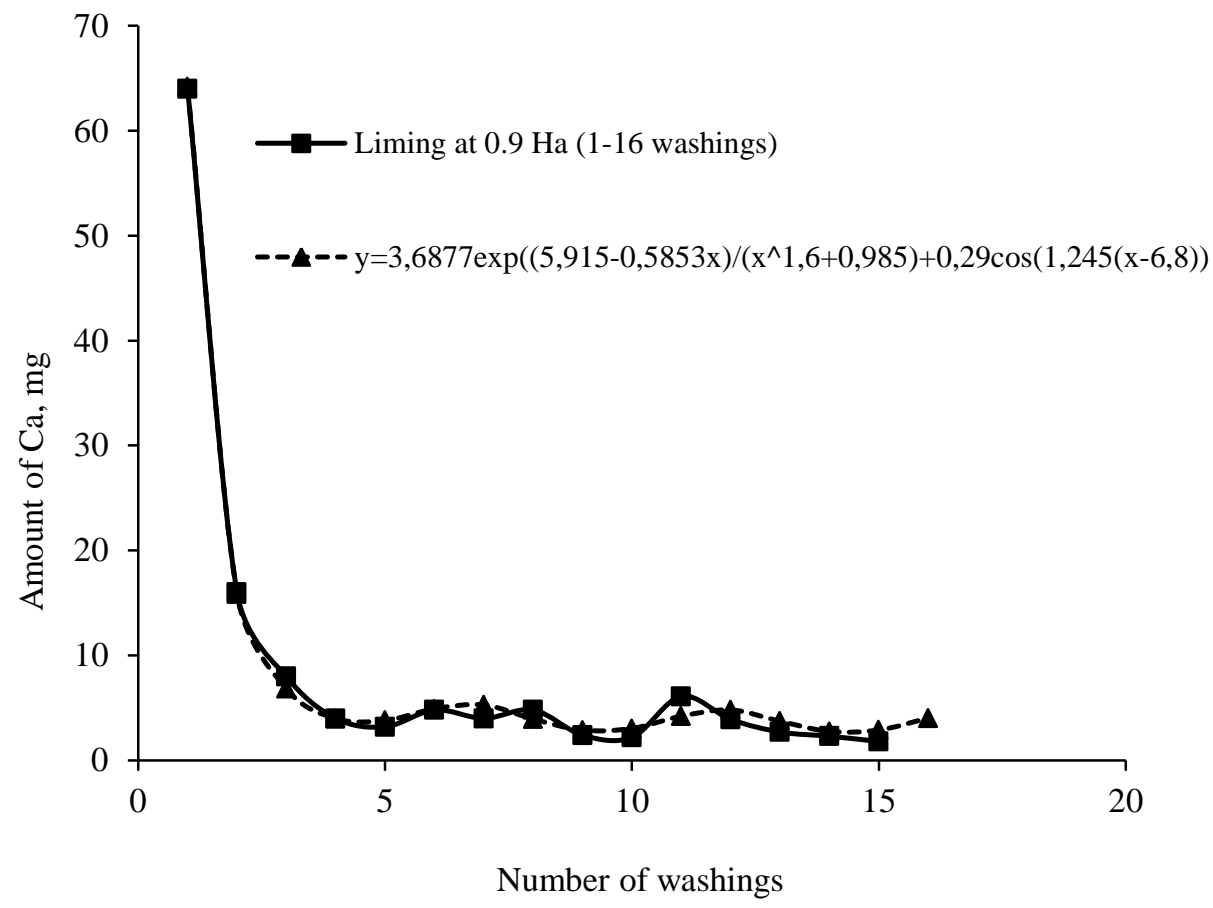

Figure 1 Dynamic of Ca leaching from soil limed with chalk at 0.9 Ha during 16 washings

Figure 2 shows the dependence (2) and the experimental results for the first five washes in $0.9 \mathrm{Ha}$ liming treatment.

Figure 3 shows the experimental results for the all sixteen washings of the soil lime with $2.5 \mathrm{Ha}$ and a plot of empirical dependence:

$$
y(x)=9,11572 e^{\frac{14,19-2,64 x}{x^{2,2}+1,8}+0,2 \cos (0,995(x-4))}
$$


In the model (3) the standard deviation was $S=0.71$, which also indicates a good fit of the model (3) to the experimental data.

The general character of the dynamics of $\mathrm{Ca}$ when liming with $2.5 \mathrm{Ha}$ was the same as for $0.9 \mathrm{Ha}$, but a sharp drop in the index occurred more rapidly (Fig. 3).Already in the third washing the second phase of the dynamic has started - the oscillatory process was stable, while the value of the indicator at the second washing was less than $7 \%$ of the value at the first washing, i.e., $6.49 \%$.

This experiment allows making an important practical conclusion: the attempt to apply a deliberately high amount of finely ground ameliorant, counting on the creation of a "reserve" of calcium in soil is ineffective and leads to increased unproductive losses of $\mathrm{Ca}$ due to leaching.

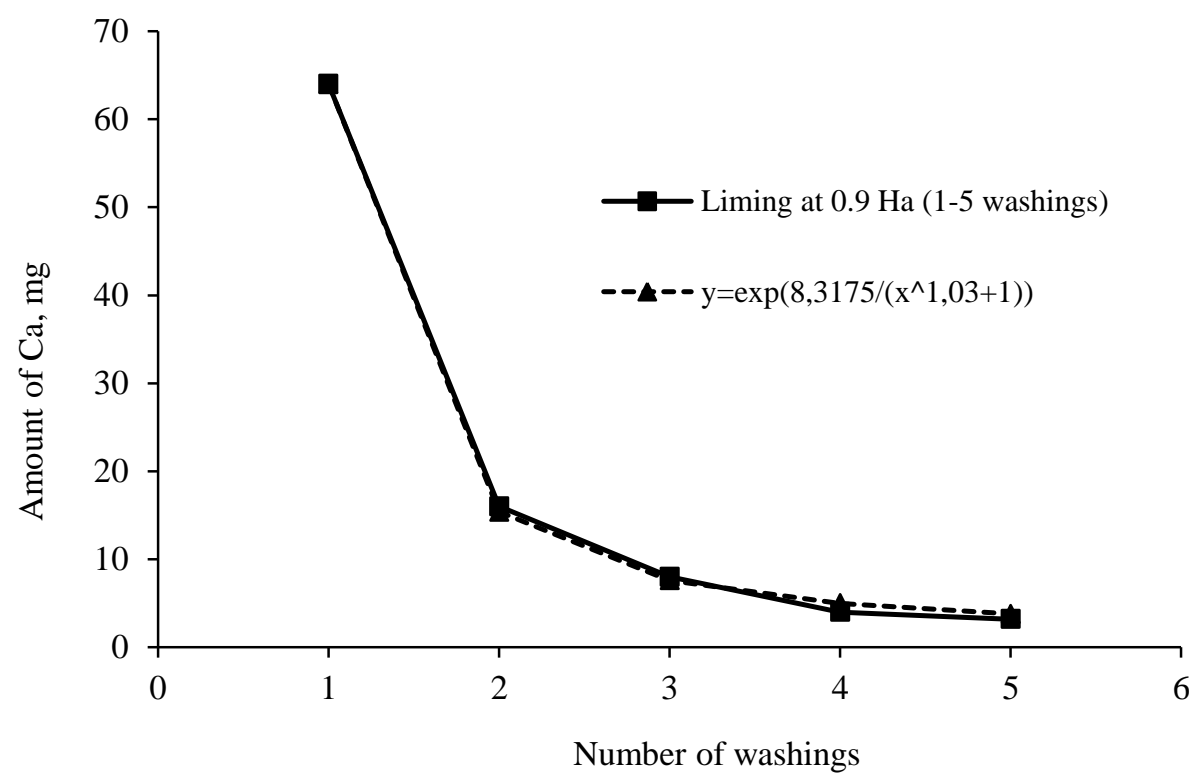

Figure 2 Dynamic of Ca leaching from soil limed with chalk at 0.9 Ha in 5 washings 


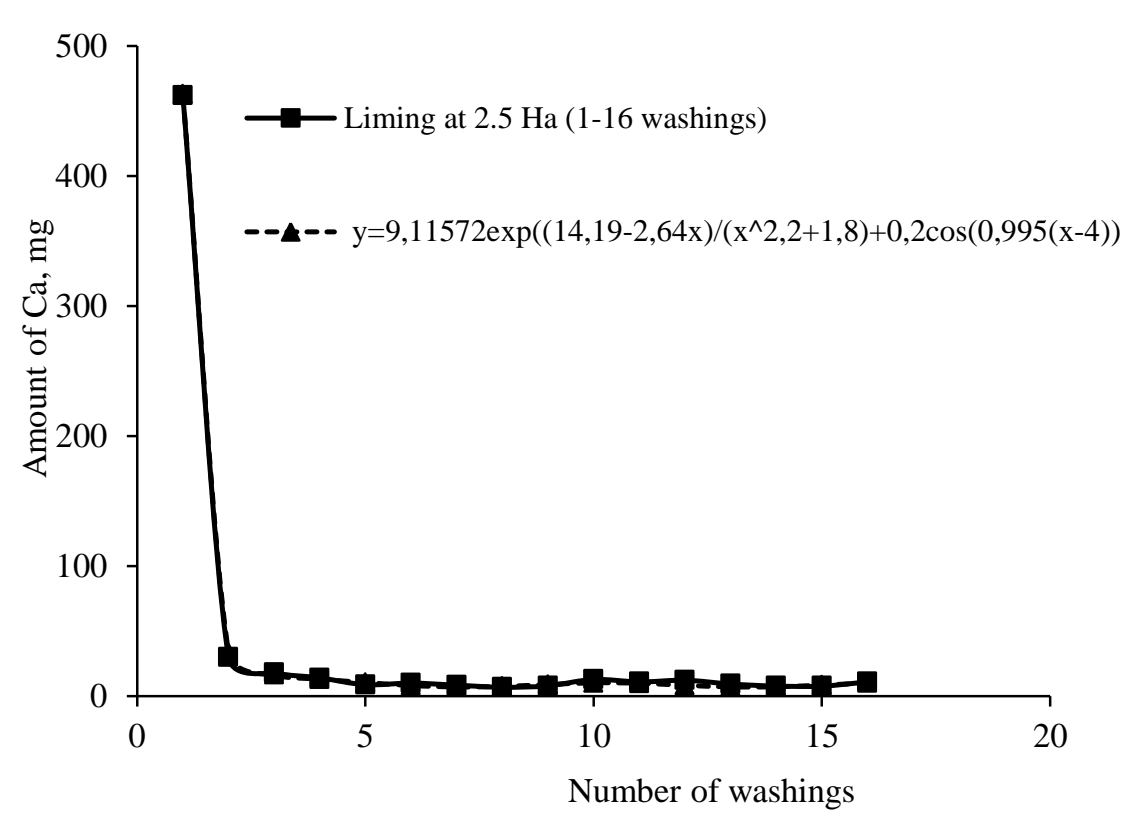

Figure 3 Dynamic of Ca leaching from soil limed with chalk at $2.5 \mathrm{Ha}$ in 16 washings

Important is, despite the significant loss of calcium from the soil due to vertical migration the complete removal of water-soluble $\mathrm{Ca}$ in none of the treatments was achieved. In both treatments the amount of calcium extracted from the soil by distilled water after 16 washes was established at $21-22 \mathrm{mg} \mathrm{kg}^{-1}$ of soil mass. Similar results were obtained by Fernández-Sanjurjo (2014) on column experiment with NPK fertilization.

\section{CONCLUSIONS}

After 16 washes of the soil limed with a dose of chalk corresponding to $0.9 \mathrm{Ha}$, the $133.4 \mathrm{mg}$ of $\mathrm{Ca}$ was removed, and from the soil limed with increased dose - $637.4 \mathrm{mg}$. An increase in the chalk dose by 2.7 times increased the loss of calcium by 4.8 times

The use of a deliberately increased dose of ameliorant aimed to make a "reserve" of Ca in soil is ineffective because leads to an increase in non-productive losses of this element.

The dynamic of the migration of calcium from the soil limed with scientifically-based and deliberately increased doses of chalk is of a similar nature.

Soil buffer system: exchangeable calcium $\leftrightarrow$ calcium of the soil solution, maintains the presence of some amount of water-soluble calcium. 


\section{REFERENCES}

Adomaitis T, Staugaitis G, Mažvila J, Vaišvila Z, Arbačiauskas J, Lubytė J, Šumskis D, Švėgžda A.2013: Leaching of base cations as affected by a forty-year use of mineral fertilisation. Zemdirbyste-Agriculture, 100(2):119-126 DOI 10.13080/z-a.2013.100.015

Bakina LG. 2012:Role of fractions of humic matters in soil-ecological processes. DoctoralThesis, St. Petersburg, 399 p.

Bélanger N, Paré D, Hendershot WHCh. 2008: Determining Nutrient Availability in Forest Soils.In: Martin R. Carter \& E.G. Gregorich (Eds). Soil Sampling and Methods of Analysis. Canadian Society of Soil Science, Taylor \& Francis Group for CRC Press.

Fernández-Sanjurjo MJ, Alvarez-Rodríguez E, Núñez-Delgado A, Fernández-Marcos ML, Romar-Gasalla A. 2014: Nitrogen, phosphorus, potassium, calcium and magnesium release from two compressed fertilizers: column experiments. Solid Earth 5:13511360, doi:10.5194/se-5-1351-2014.

Goulding GWT. 2016: Soil acidification and the importance of liming agricultural soils with particular reference to the United Kingdom.Soil Use Management, 32(3):390399.doi: $10.1111 /$ sum. 12270

Hendershot WH, Lalande H, Duquette M. 2008: Soil pH, Effective Cation Exchange Capacity, \& Exchangeable Cations (in Forest Soils).In: Martin R. Carter \& E.G. Gregorich(Eds.),Ion Exchange and Exchangeable Cations, Ch. 18. Canadian Society of Soil Science, Taylor \& Francis Group for CRC Press.

Holland JE, Bennett AE, Newton AC, White PJ, McKenzie BM, George TS, Pakeman RJ, Bailey JS, Fornara DA, Hayes RC. 2018: Liming impacts on soils, crops and biodiversity in the UK: A review. Science of the Total Environment, 610-611(1):316332.

IUSS-WRB: World Reference Base for Soil Resources: World Soil Resources Reports, No. 103, FAO, Rome, Italy, (2007).

Kabrick JM, Goyne KW, Fan Zh, Mainert D. 2011: Landscape determinants of exchangeable calcium and magnesium in Ozrak Highland forest soils. Soil Sci. Soc. Am. J. 75(1):164180.

Kaurichev IS, Yashin IM. 1973: Theoretical substantiation of the lysimeter, chromatography columns. News of Timiryazev Agrarian Academy. 3:89-98 
Kopáček J, Kaňa J, Bičárová S, Fernandez IJ, Hejzlar J, Kahounová M, Norton SA, Stuchlík E. 2017: Climate Change Increasing Calcium and Magnesium Leaching from Granitic Alpine Catchment. Environ Science and Technol., 51(1):159-166. doi: 10.1021/acs.est.6b03575.

Lapenis AG, Lawrence GB, Bailey SW, Aparin BF, Shiklomanov AI, Speranskaya N A, Torn MS, Calef M. 2008: Climatically driven loss of calcium in steppe soil as a sink for atmospheric carbon, Global Biogeochemistry Cycles, 22, GB2010, doi:10.1029/2007GB003077.

Lehmann J, Schroth G. 2003: Nutrient leaching.InG. Schroth and F.L. Sinclair (Eds.)Trees, Crops and Soil Fertility,Chapter 7,pp. 151-166, CAB International.

Litvinovich AV. 2007: Spatial heterogeneity of agrochemical indicators of arable sodpodzolic soils. Agrochemistry, 5:89-94.

Litvinovich AV, Nebolsina ZP. 2012: The duration of action of ameliorants in soils and the effectiveness of liming. Agrochemistry, 10:79-94

Litvinovich AV, Pavlova OYu, Lavrishchev AV. 1999: About leaching of calcium and strontium from soddy-podzolic sandy loam soil, chalked with conversion chalk. Agrochemistry, 9:64-67.

Litvinovich AV, Pavlova OYu, Lavrishchev AV, Saljnikov E. 2017:Empirical models of transformations of humic acids and humin in Umbric Albeluvisol Abruptic as influenced by liming. Zemdirbyste-Agriculture, 104(2):115-122. DOI 10.13080/za.2017.104.015

Paradelo R, Virto I, Chenu C. 2015: Net effect of liming on soil organic carbon stocks: A review. Agriculture, Ecosystems and Environment, 202:98-107. https://doi.org/10.1016/j.agee.2015.01.005

Pestryakov VK. 1987: Removal of substances from the soil by drainage runoff and its impact on the environment. In: Usage of fertilizers in conditions of intensification of agriculture in the Northwest of the Russian Federation, pp.82-89.

Pousada-Ferradás Y, Seoane-Labandeira S, Mora-Gutiérrez A, Núñez-Delgado A. 2012: Risk of water pollution due to ash-sludge mixtures: column trials. Int'l J.Environ. Sci. and Technol. 9:1-29. 
Sekine Yu, Motokawa R, Kozai N, Ohnuki T, Matsumura D, Tsuji T, Kawasaki R, Akiyoshi K.2017:Calcium-deficient Hydroxyapatite as a Potential Sorbent for Strontium. Sci Rep., 7, 2064. doi: 10.1038/s41598-017-02269-z

Shepherd MA, Bennett G. 1998: Nutrient leaching losses from a sandy soil in lysimeters. Communications in Soil Science and Plant Analysis, 29(7-8):931-946 DOI 10.1080/00103629809369997

Shilnikov IA, Akanova NI, Fedotova LS. 2004: Determination of calcium losses from arable soils in the field experiments. Plodorodie, 2:21-23.

Shilnikov IA, Lebedeva LA. (Eds) 1987: Limingsoils. Moscow, Agropromizdat, 167 p.

Youngil C, Driscoll CT, Johnson CE, Siccama TG. 2009: Chemical Changes in Soil and Soil Solution after Calcium Silicate Addition to a Northern Hardwood Forest. Biogeochemistry, 100(1-3):3-20. doi:10.1007/s10533-009-9397-6. 


\title{
Eluvijalni gubici Ca iz Umbric Albeluvisols Abruptic tretiranog različitim dozama kreča
}

\author{
Olga Pavlova ${ }^{1}$, Andrey Litvinovich $^{1}$, Anton Lavrishchev ${ }^{2}$, Vladimir Bure ${ }^{1,3}$, Elmira Saljnikov $^{4 *}$ \\ ${ }^{1}$ Agrophysical Research Institute, Grazhdanskiy 14, 195220 St. Petersburg, Russia \\ ${ }^{2}$ St. Petersburg State Agrarian University, Peterburgsoye 2, 196601 St. Petersburg, Pushkin, Russia \\ ${ }^{3}$ St. Petersburg State University, UniversitetskayaEmb. 7/9, 199034 St. Petersburg, Russia, \\ ${ }^{4}$ Soil Science Institute, Teodora Drajzera 7, 11000 Belgrade, Serbia \\ *Corresponding author:soils.saljnikov@gmail.com
}

Na zemljištu tipa Umbric Albeluvisols Abruptic su vršeni ogledi u cilju utvrđivanja gubitaka kalcijuma iz zemljišta uz primenu meliorativne mere kalcizacije, sa unosom različitih doza kreča. Radi definisanje dinamike ispiranja kalcijuma je vršeno 16 vodenih ispiranja zemljišta. U ogledu su primenjena dva tretmana kalcizacije (1) sa optimalnom dozom kreča (2) sa povećanom dozom kreča uz primenu meliorativnog sredstva slične prirode. Naglo ispiranje kalcijuma je utvrđeno u prvih pet ispiranja u prvom tretmanu, dok u drugom tretmanu je utvrđeno u prva tri ispiranja. Nakon toga daljim ispiranjem je došlo do stabilizacije gubitaka kalcijuma iz zemljišta. Povećana doza kreča za 2.7 puta je takođe dovela do povećanih gubitka kalcijuma za 4.8 puta. Na osnovu dobijenih rezultata je zaključeno da unošenje povećane doze kreča u zemljište kao meliorativne mere u cilju stvaranja određene rezerve kalcijuma za biljke je neefikasno usled povećanih gubitka kalcijuma iz zemljišta. Takođe je u uočeno da zemljište poseduje puferne sposobnosti koje održavaju ravnotežu između razmenjivog kalcijuma i kalcijuma rastvorenog u zemljišnom rastvoru. Na taj način je omogućeno da se čak i u uslovima intezivnog vlaženja održava prisustvo određne količine kalcijuma rastvorljivog u vodi

Ključne reči: gubici kalcijuma; krečenje; empirijski modeli 